\title{
Postoperative environmental anesthetic vapour concentrations following removal of the airway device in the operating room versus the postanesthesia care unit
}

\section{Les concentrations de vapeurs anesthésiques dans l'environnement postopératoire après le retrait du dispositif de ventilation en salle d'opération versus en salle de réveil}

\author{
Sara K. Cheung, MBBS · Timur Özelsel, MD • Saifee Rashiq, MB • Ban C. Tsui, MD \\ Received: 22 December 2015/Revised: 16 April 2016/Accepted: 1 June 2016/Published online: 6 June 2016 \\ (C) Canadian Anesthesiologists' Society 2016
}

\begin{abstract}
Purpose This study was designed to compare waste anesthetic gas (WAG) concentrations within patients' breathing zones after removal of the patient's airway device in the postanesthesia care unit (PACU) vs in the operating room $(O R)$.

Methods Following Research Ethics Board approval and patient consent, we recruited patients undergoing surgery who received volatile anesthesia via an endotracheal tube or supraglottic airway. Patients had their airway device removed in the OR or in the PACU depending on the attending anesthesiologist's preference. Upon the patient's arrival in the PACU, concentrations of exhaled sevoflurane and desflurane were measured at their breathing zone (i.e., $15 \mathrm{~cm}$ from the patient's mouth and nose) using a singlebeam infrared spectrophotometer.

Results Seventy patients were recruited during the fivemonth study period. The median [interquartile range] WAG levels in the patients' breathing zones were higher when their airway devices were removed in the PACU vs in the OR. The WAG levels for sevoflurane were 0.7 [0.4-1.1] parts per million (ppm) vs 0.5 [0.4-0.7] ppm, respectively; median difference, 0.3 ; 95\% confidence interval (CI), 0.1 to $0.6 ; P=0.04$. The WAG levels for desflurane were 2.4
\end{abstract}

S. K. Cheung, MBBS

Department of Anaesthesia, Pamela Youde Nethersole Eastern Hospital, Hong Kong, SAR, China

T. Özelsel, MD ( $ه) \cdot$ S. Rashiq, MB · B. C. Tsui, MD Department of Anesthesiology \& Pain Medicine, University of Alberta, 2-150 Clinical Sciences Building, Edmonton, AB T6G 2G3, Canada

e-mail: ozelsel@ualberta.ca
[1.2-3.4] ppm vs 4.1 [2.5-5.2] ppm, respectively; median difference, $1.5 ; 95 \%$ CI, 0.3 to $2.7 ; P=0.04$.

Conclusions After a volatile-based anesthetic, our results suggest that removal of the airway device in the PACU vs in the OR increases the amount of waste anesthetic gas in a patient's breathing zone and thus potentially in the PACU nurse's working zone.

Résumé

Objectif Cette étude a été conçue pour comparer les concentrations de gaz anesthésiques résiduels (GAR) dans la zone de respiration des patients après le retrait du dispositif de ventilation du patient en salle de réveil versus en salle d'opération (SO).

Méthode Après avoir reçu le consentement du Comité d'éthique de la recherche, nous avons recruté des patients subissant une chirurgie et ayant reçu une anesthésie par inhalation via une sonde endotrachéale ou un dispositif supraglottique. On a retiré le dispositif de ventilation des patients en $\mathrm{SO}$ ou en salle de réveil, selon la préférence de l'anesthésiologiste en charge. À l'arrivée du patient en salle de réveil, les concentrations de sévoflurane et de desflurane expirés ont été mesurées dans la zone de respiration des patients (soit à $15 \mathrm{~cm}$ du nez et de la bouche du patient) à l'aide d'un spectrophotomètre à infrarouge à faisceau unique.

Résultats Soixante-dix patients ont été recrutés au cours de la période de cinq mois qu'a duré notre étude. Les niveaux moyens [écart interquartile] de GAR dans les zones de respiration des patients étaient plus élevés lorsque les dispositifs de ventilation étaient retirés en salle de réveil plutôt qu'en SO. Les niveaux de GAR de sévoflurane étaient de 0,7 [0,4-1,1] partie par million (ppm) vs 0,5 [0,4-0,7] ppm, respectivement; différence médiane, 0,3; 
intervalle de confiance (IC) $95 \%, 0,1$ à 0,6; $P=0,04$. Les niveaux de GAR de desflurane étaient de 2,4 [1,2-3,4] parties par million (ppm) vs 4,1 [2,5-5,2] ppm, respectivement; différence médiane, 1,5; IC 95\%, 0,3 à 2,7; $P=0,04$.

Conclusion Après une anesthésie volatile, nos résultats suggèrent que le retrait du dispositif de ventilation en salle de réveil plutôt qu'en $S O$ augmente la quantité de gaz anesthésiques résiduels dans la zone de respiration du patient et, par conséquent, potentiellement dans la zone de travail de l'infirmière de salle de réveil.

Nurses and other healthcare workers work frequently within patients' breathing zones while in the postanesthesia care unit (PACU). These workers are constantly exposed to waste anesthetic gas (WAG) exhaled by the recovering patients, and WAG exposure levels often exceed limits set by the National Institute for Occupational Safety and Health (NIOSH). ${ }^{1}$ In the past decades, experimental, epidemiological, and other clinical studies have shown that exposure to anesthetic gases may be associated with adverse health outcomes, particularly carcinogenic and teratogenic effects. ${ }^{2-8}$ Although many of these studies have been questioned regarding their validity secondary to methodological flaws and practices that are no longer standard of care, studies are lacking to suggest that WAG is harmless. Indeed, the current working hypothesis of all major healthcare systems worldwide is to reduce the amount of WAG to which healthcare workers are exposed. As a result, various systems and work practices have been developed to achieve this goal. ${ }^{9,10}$ Though much emphasis has been placed on mitigating exposure in operating rooms (ORs), WAG exposure in the PACU can be significant and is frequently neglected. ${ }^{11-13}$

At the University of Alberta Hospital, a common anesthetic practice is to bring patients to the PACU prior to removal of their airway device [i.e., endotracheal tube (ETT) or supraglottic airway (SGA)] and to let the PACU nurses remove the device. The advantage of this approach is presumed to be a faster rate of turnover in the OR and better utilization of resources. ${ }^{14-16}$ Because the breathing circuit is often disconnected from the patient's airway in the OR before most anesthetic vapours are eliminated, we postulated that this practice might have an effect on the WAG level in the patients' breathing zones and thus in the PACU nurses' working zone.

The purpose of this study was to compare WAG concentrations within patients' breathing zones in the PACU after removal of the patient's airway device in the OR $v s$ in the PACU. We hypothesized that patients arriving
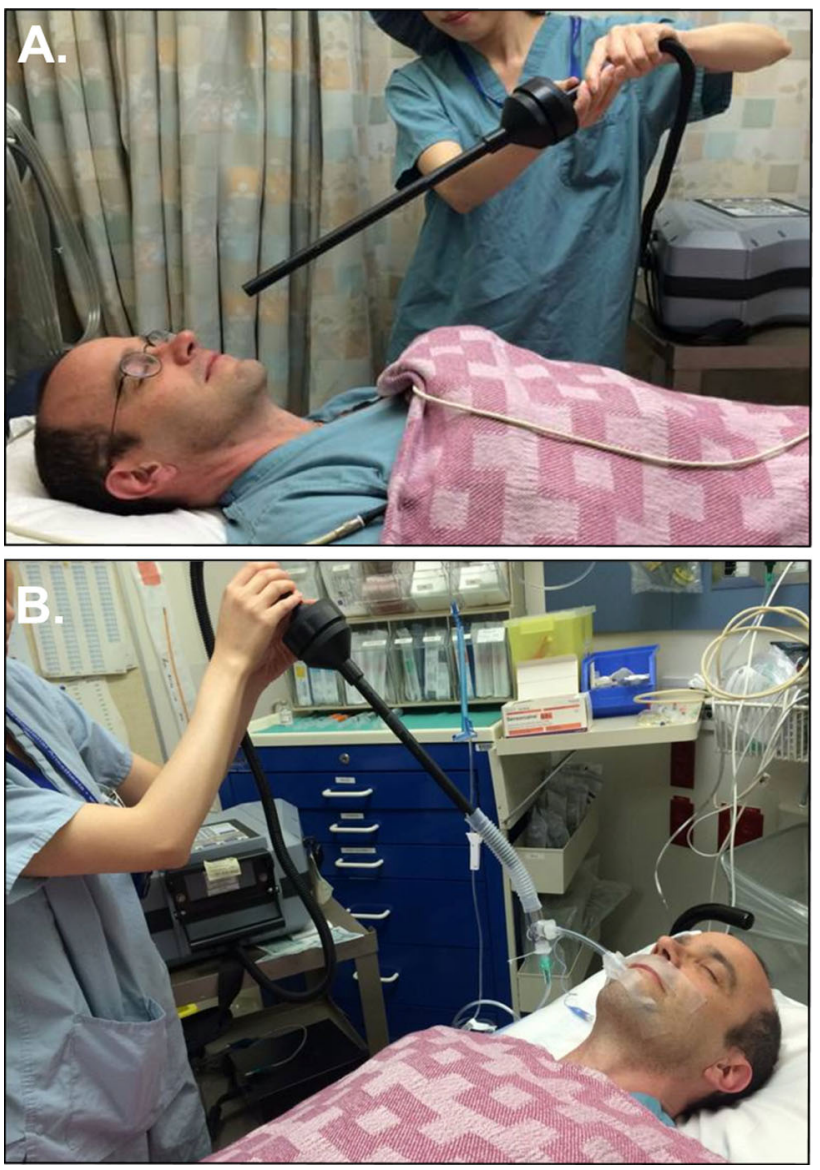

Figure (A) Photo showing method for obtaining breath samples of patients without an airway device. The distal end of the analyzer is placed six inches from the patient's mouth and nose. (B) Photo showing method for obtaining breath samples of patients with an airway device. Samples were obtained inside the T-piece near the distal end of the airway device within six inches of the tube outlet

in the PACU with an airway device in situ would have higher blood concentrations of volatile anesthetics, and as a result, we expected a significantly higher level of measurable WAG around the breathing zone of these patients.

\section{Methods}

The University of Alberta Health Research Ethics Board gave approval for this study (June 2014), and all participants provided written informed consent. Recruitment took place from September 2014 to February 2015. Inclusion criteria included patients undergoing any surgery and receiving general anesthesia with volatile anesthetic gases and insertion of an ETT or SGA. Supraglottic airways used were the LMA Classic ${ }^{\mathrm{TM}}$ and the LMA ProSeal ${ }^{\mathrm{TM}}$ (Teleflex Medical; Research Triangle Park, NC, USA). Patients who were unable to provide 
Table 1 Patient demographics and intraoperative characteristics

\begin{tabular}{lcr}
\hline Group & OR airway removal $(n=30)$ & PACU airway removal $(n=39)$ \\
\hline Age $(\mathrm{yr})$ & $57(16)$ & $51(16)$ \\
BMI $\left(\mathrm{kg} \cdot \mathrm{m}^{-2}\right)$ & $22.9(4.3)$ & $22.5(4.1)$ \\
Sevoflurane & $13(43 \%)$ & $28(72 \%)$ \\
Desflurane & $17(57 \%)$ & $11(28 \%)$ \\
\hline
\end{tabular}

Data are represented as mean (standard deviation) where indicated; BMI = body mass index; OR = operating room; PACU = postanesthesia care unit.

written consent were excluded from the study. Patient selection represented a convenience sample from days on which research staff were available with the proper equipment to take measurements.

Measurements were taken in the adult PACU of the University of Alberta Hospital, a rectangular room measuring $188 \mathrm{~m}^{2}$ with a room volume of $488 \mathrm{~m}^{3}$ and nine patient bays. The PACU was built to exceed all current standards regarding ventilation, including centrally located air supply vents and exhaust vents $(15 \mathrm{~cm}$ off the floor and protected by a guard to avoid obstruction) at every patient bay. Ventilation occurs with a minimum of 17 total air exchanges per hour, ten of which are fresh gas exchanges. The building standard requires six total air exchanges, two of which must be fresh gas exchanges. ${ }^{17,18}$ There is a positive pressure gradient relative to adjacent areas, and the temperature is kept within $18-26^{\circ} \mathrm{C}$ with a relative humidity of $20-60 \%$.

Waste anesthesia gas was sampled and analyzed by a single-beam infrared spectrophotometer (MIRAN $^{\circledR}$ 205B Series SapphIRe Portable Ambient Air Analyzer; Thermo Electron Corporation, Waltham, MA, USA), and the anesthetic gas (sevoflurane or desflurane) concentrations were measured. The MIRAN SapphIRe determines the concentrations of various gases by measuring changes to the wavelength and the path length of infrared light. It has an accuracy of $\pm 10 \%$ and a detection limit of 0.04 parts per million (ppm) for each of the two measured gases. The machine was zeroed outside the OR suite every morning and every eight hours after use according to the manufacturer's recommendation.

To obtain exhaled breath samples, the wand of the analyzer was placed manually within $15 \mathrm{~cm}$ of the patient's mouth and nose, which defined the "patient's breathing zone" (Figure A). ${ }^{10}$ For those with an airway device in place, local practice is to connect the device to oxygen at $10 \mathrm{~L} \cdot \mathrm{min}^{-1}$ of flow via a T-piece. In these patients, the samples were taken inside the T-piece near the distal end of the ETT or SGA in order to obtain measurements that were within $15 \mathrm{~cm}$ of the outlet of the device (Figure B). The decision whether to remove the airway device in the OR or in the PACU was left to the discretion of the responsible anesthesiologist. Measurements were taken as soon as the patient arrived in the PACU (time 0).

The following data were recorded and manually transferred onto a clinical report form: sevoflurane or desflurane concentrations in ppm, demographic data, PACU arrival and discharge time, type of halogenated agent used, use of nitrous oxide $\left(\mathrm{N}_{2} \mathrm{O}\right)$, and the time taken to remove the airway in the PACU. The investigators collecting the data were not involved in providing anesthesia for the patients.

\section{Statistical analysis}

As we lacked detailed aspects of relevant data to allow for a formal sample size calculation; consequently, a fivemonth study period was selected for convenience of manpower resources. The study's null hypothesis was that there would be no difference in the WAG levels of sevoflurane or desflurane on arrival in the PACU whether the airway device was removed in the OR or left in place until PACU admission. We used the Shapiro-Wilk test to assess the normality of the distributions of WAG levels by site of airway device removal. The WAG levels were summarized using median [interquartile range (IQR)]. The Wilcoxon rank-sum test was used to test the difference in WAG levels between the groups, and the Hodges-Lehmann method was used to estimate the between-group difference in medians and the $95 \%$ confidence interval (CI) of the difference between group medians. Separate analyses were performed for sevoflurane and desflurane. All reported $P$ values are two sided after Bonferroni correction. Analyses were performed using SAS ${ }^{\circledR} 9.4$ (SAS Institute Inc., Cary, NC, USA).

\section{Results}

Seventy patients completed the study. One subject in the PACU group received both sevoflurane and desflurane and was excluded from analysis. Thirty (43\%) of the remaining 69 patients had their airway device removed in the OR, and $39(56 \%)$ of the 69 had their airway device removed in the 
Table 2 Waste anesthetic gas levels in each patient group.

\begin{tabular}{lllll}
\hline & $\begin{array}{l}\text { WAG level }(\mathrm{ppm}): \\
\text { OR airway removal }\end{array}$ & $\begin{array}{l}\text { WAG level }(\mathrm{ppm}): \\
\text { PACU airway removal }\end{array}$ & $\begin{array}{l}\text { Estimated between-group } \\
\text { difference in medians }(95 \% \mathrm{CI})^{*}\end{array}$ \\
\hline Sevoflurane & $0.5[0.4-0.7]$ & $0.7[0.4-1.1]$ & $0.3(0.1$ to 0.6$)$ & 0.04 \\
Desflurane & $2.1[1.6-3.3]$ & $4.1[2.5-5.2]$ & $1.5(0.3$ to 2.7$)$ & 0.04 \\
\hline
\end{tabular}

Data are represented as median [interquartile range] where indicated

* Hodges-Lehmann estimation

** Wilcoxon rank-sum test after Bonferroni's correction

$\mathrm{CI}=$ confidence interval; $\mathrm{OR}=$ operating room; PACU = postanesthesia care unit; ppm = parts per million; WAG = waste anesthetic gas.

PACU. Table 1 gives descriptive characteristics of the two groups and the proportion of each group receiving each gas.

Among the patients whose airway device was removed in PACU, the median [IQR] time for removal was 4.5 [2.86.3] min for the sevoflurane group and 5.0 [3.5-14.0] $\mathrm{min}$ for the desflurane group. Regardless of the anesthetic gas used, when the airway device was removed in the PACU, the WAG levels were higher than in the OR (Table 2). The WAG levels for sevoflurane were 0.7 [0.4-1.1] parts per million (ppm) vs 0.5 [0.4-0.7] ppm, respectively; median difference, $0.3 ; 95 \%$ confidence interval $(\mathrm{CI}), 0.1$ to $0.6 ; P$ $=0.04$. The WAG levels for desflurane were 2.4 [1.2-3.4] ppm vs 4.1 [2.5-5.2] ppm, respectively; median difference, $1.5 ; 95 \% \mathrm{CI}, 0.3$ to $2.7 ; P=0.04$.

\section{Discussion}

This study shows that bedside WAG levels can be influenced by the location of airway device removal in patients maintained with inhalational agents and, specifically, that WAG levels are higher when the airway device is removed in the PACU. Importantly, it is during the early recovery phase in the PACU that patients generally require the most intensive bedside nursing care and closest monitoring of vital signs. This is also the time when patients exhale the largest amount of WAG, especially when coughing. ${ }^{11}$ Since the main source of WAG in the PACU is from patients' exhaled breath, this may have a potential impact on the exposure of nurses and other healthcare workers to WAG.

A previous study showed that the highest quantitative readings of WAG within the patients' breathing zones occur within the first 15 min after removal of their airway device. ${ }^{19}$ In that study, 19 adult patients who had general anesthesia with sevoflurane (with or without nitrous oxide) were studied. All patients were tracheally intubated upon their arrival in the PACU, and measurements were started after tracheal extubation. Similarly, our results also showed that patients arriving at the PACU with an ETT or SGA in place had significantly higher exhaled levels of both sevoflurane and desflurane than those undergoing tracheal extubation in the OR. While there can be multiple reasons for ETT tolerance following general anesthesia, we hypothesized that our patients still had residual general anesthesia secondary to persisting high levels of circulating volatile anesthetics. For those patients whose ETT or SGA was removed in the OR, most residual anesthetic gases were washed out from the patients' lungs by the fresh gas flow and were eliminated by the scavenging system while the anesthetic machines were still connected to the patients. For patients whose airway device was removed in the PACU, the breathing circuits were often disconnected early while high concentrations of residual anesthetic gases remained in the patients' bodies. These patients, with ETT or SGA in situ, were brought to the PACU where the residual anesthetic gases were passively (i.e., without active scavenging) eliminated. Nevertheless, in the absence of a patient-specific scavenging system in the PACU, residual anesthetic gases were exhaled as WAG and potentially accumulated if there was insufficient air circulation. This outcome is supported by our findings that patients whose airway device was removed in the PACU $v s$ in the OR yielded a higher initial concentration of WAG.

Anesthetic gases have been used for more than 125 years and continue to be the mainstay of general anesthesia worldwide. In 1967, Vaisman published the first report on the adverse health effects of occupational exposure to WAGs, ${ }^{2}$ including a higher incidence of headache, fatigue, nausea, irritability, and spontaneous abortions among female anesthesiologists. Over the subsequent few years, various epidemiological studies supported the findings of an increased rate of spontaneous abortions $\mathrm{s}^{3-7}$ as well as a higher incidence of congenital anomalies ${ }^{4,6,7}$ associated with chronic exposure of healthcare workers to anesthetic gases. In 1974, the American Society of Anesthesiologists conducted a nationwide survey and reported elevated rates of infertility, spontaneous abortion, congenital abnormalities, premature births, cancer, and renal and hepatic diseases in healthcare workers exposed to WAGs. ${ }^{8}$ 
Three years later, the NIOSH set its recommended exposure limits at $25 \mathrm{ppm}$ for $\mathrm{N}_{2} \mathrm{O}, 2 \mathrm{ppm}$ for halogenated agents when used alone, and $0.5 \mathrm{ppm}$ when the halogenated agent is used together with $\mathrm{N}_{2} \mathrm{O}$ over a sampling period of less than one hour. ${ }^{20}$ Nevertheless, there were, and still are, debates about the long-term effects of WAG since evidence from the aforementioned studies is mainly from retrospective epidemiological questionnaires, many of which contained methodological flaws. ${ }^{21}$ More recent studies have examined the potential genotoxicity of WAG. All studies show DNA damage and/or a reduction of antioxidant defence in OR personnel compared with control subjects, both with and without $\mathrm{N}_{2} \mathrm{O}$ present. ${ }^{22-24}$ While the authors attribute the damage to WAG, there is no way to isolate for their effect. Stress, lack of sleep, irregular nutrition, and environmental factors are also known or suspected to cause DNA damage. ${ }^{25-27}$ It is clearly difficult to design a study that can isolate for the pure effects of WAG. Importantly, however, chronic exposure to WAG has yet to be proven harmless. The general consensus worldwide is to adopt measures to reduce occupational exposure to $\mathrm{WAG}$ in an effort to minimize any potential health consequences. ${ }^{28-30}$ As a result, various instructions and guidelines designed to reduce the level of WAG in the workplace were developed and issued, including installation of effective scavenging and ventilation systems, work practice controls, medical surveillance, and regular monitoring of WAG levels. ${ }^{9,10}$

Our study indicates that removal of the airway device in the PACU tends to be associated with higher ambient concentrations of WAG. This represents an ideal starting point for further research with a larger sample size and may also reveal the most crucial time(s) to shield PACU nurses from exhaled WAG. One such safeguard could be to implement source control measures in cases where patients need their airway device removed in the PACU. Various source control systems have been studied and have been shown to be useful in controlling the amount of WAG, including the AirCare Source Control System and the IsoGard $^{\circledR}$ mask. ${ }^{1,19}$ Other work practices have been suggested, such as avoiding the patient's breathing zone whenever possible, especially when they are coughing or talking, and charting the patient's record at the foot of the bed. These measures, together with a well-maintained effective ventilation system, are keys to minimizing WAG levels and occupational exposure in the PACU.

A limitation of this study is that our results do not reveal how long the differences in WAG levels persist in the OR $v s$ in the PACU. Additionally, we measured WAG only in patients' breathing zones, which means that the values measured cannot be extrapolated to an eight-hour timeweighted average since this would likely overestimate healthcare workers' actual exposure to WAG. Although technically more challenging, it would be ideal and more representative of actual exposure to measure the WAG level within the breathing zones of healthcare workers providing bedside care. Indeed, measurement of WAG levels in the PACU is often obtained in the middle of the room rather than at the bedside, and therefore, previous results are not representative of the amount of WAG to which healthcare workers are exposed. ${ }^{11}$ Another limitation is the dilution of measured air in the patients' breathing zones. Tidal volumes and minute respiration will be different from patient to patient following surgery and may be prone to errors. The same applies to measuring air at the outlet of the T-piece since patients may have different surplus flows of oxygen depending on their current need and thus minute volumes. Although baseline comparisons of patient age and weight were similar between the two groups, we did not compare other factors such as duration of anesthetic and depth of anesthetic upon arrival at the PACU. It is possible that these confounding factors may influence exhaled WAG concentrations. A fourth potential limitation is that the setup for measurement was different for the OR and PACU groups. For ease and practical reasons, measurements in the OR group were performed in the open air, while measurements in the PACU group were taken inside the Tpiece. This may have potentially resulted in higher readings in the PACU group before extubation due to a confined sampling environment. Finally, in some cases, cross contamination of WAGs from neighbouring patients could have resulted in false high readings.

\section{Conclusions}

After patients received a volatile-based anesthetic, we have shown significantly higher WAG levels in patients' breathing zones following airway device removal in the PACU $v s$ in the OR. This observation raises environmental and occupational concerns regarding the safety of this practice.

Acknowledgements The authors thank Seok Hee Kim for assistance with the study and Dr. Gareth Corry for assistance with the manuscript.

Funding Dr. Tsui is supported by a Clinical Scholar Award from the Alberta Heritage Foundation for Medical Research (AHFMR). Dr. Tsui's research is supported by the Canadian Anesthesia Research Foundation.

Conflicts of interest None declared.

Author contributions Sara K. Cheung, Timur Özelsel, and Ban C. Tsui were involved in the study design. Sara K. Cheung and Timur Özelsel were involved in data collection. Sara K. Cheung, Timur 
Özelsel, Saifee Rashiq, and Ban C. Tsui were involved in the data analysis and in drafting the manuscript.

Editorial responsibility This submission was handled by Dr. Hilary P. Grocott, Editor-in-Chief, Canadian Journal of Anesthesia.

\section{References}

1. Badgwell JM. A clinical evaluation of an operational postanesthesia care unit source control system. J Perianesth Nurs 1997; 12: 73-81.

2. Vaisman AI. Working conditions in the operating room and their effect on the health of anesthetists (Russian). Eksp Khir Anesteziol 1967; 12: 44-9.

3. Askrog V, Harvald B. Teratogenic effects of inhalation anesthetics (Danish). Nord Med 1970; 83: 498-500.

4. Cohen EN, Bellville JW, Brown BW Jr. Anesthesia, pregnancy, and miscarriage: a study of operating room nurses and anesthetists. Anesthesiology 1971; 35: 343-7.

5. Knill-Jones RP, Newman BJ, Spence AA. Anesthetic practice and pregnancy. Controlled survey of male anaesthetists in the United Kingdom. Lancet 1975; 2: 807-9.

6. Knill-Jones RP, Rodrigues LV, Moir DD, Spence AA. Anaesthetic practice and pregnancy. Controlled survey of women anaesthetists in the United Kingdom. Lancet 1972; 1: 1326-8.

7. Rosenberg $P$, Kirves A. Miscarriages among operating theatre staff. Acta Anaesthesiol Scand Suppl 1973; 53: 37-42.

8. American Society of Anesthesiologists. Occupational disease among operating room personnel: a national study. Report of an Ad Hoc Committee on the Effect of Trace Anesthetics on the Health of Operating Room Personnel, American Society of Anesthesiologists. Anesthesiology 1974; 41: 321-40.

9. McGregor D. Task Force on Trace Anesthetic Gases, Committee on Occupational Health. Waste Anesthetic Gases: an update on information for management in anesthetizing areas and the postanesethesia care unit. ASA Newsletter 1999; 63: 7.

10. Department of Health and Human Services; Centers for Disease Control and Prevention; National Institute for Occupational Safety and Health. Waste Anesthetic Gases: Occupational Hazards in Hospitals. Cincinnati, OH, U.S., September 2007. Available from URL: http://www.cdc.gov/niosh/docs/2007-151/ pdfs/2007-151.pdf (accessed April 2016).

11. Austin PR, Austin PJ. Measurement of nitrous oxide concentrations in a simulated post anesthesia care unit environment. J Perianesth Nurs 1996; 11: 259-66.

12. Sessler DI, Badgwell JM. Exposure of postoperative nurses to exhaled anesthetic gases. Anesth Analg 1998; 87: 1083-8.

13. Krenzischek DA, Schaefer J, Nolan M, et al. Phase I collaborative pilot study: waste anesthetic gas levels in the PACU. J Perianesth Nurs 2002; 17: 227-39.

14. Harvey $P$. Practitioner led extubation in recovery: a report into viability in the post anaesthetic care unit. J Perioper Pract 2012; 22: 296-7.
15. Francis J, Farrant J, Elliot S, Beament T. Could extubation in the PACU reduce awareness and improve theatre utilisation? Anaesthesia 2015; 70: 633-4.

16. Chillingworth S, Simpson A, Determann C, et al. Safe extubation in recovery rooms. Anaesthesia 2015; 70: 1100-1.

17. CSA Group. CSA Z8000-11 - Canadian Health Care Facilities. 2011. Toronto, CSA Group. Available from URL: http://shop.csa. $\mathrm{ca} / \mathrm{en} / \mathrm{canada} /$ landing-pages/canadian-health-care-facilities/page/ z8000 (accessed April 2016).

18. ANSI/ASHRAE/ASHE Standard 170-2013, Ventilation of Health Care Facilities. 2013. Atlanta, ASHRAE. Available from URL: http://webstore.ansi.org/RecordDetail.aspx?sku=ANSI\%2FASHRAE $\% 2$ FASHE $\% 20$ Standard $\% 20170-2013 \&$ source $=$ google $\&$ adgroup $=$ ASHRAE\&gclid=CjwKEAjw9OG4BRDJzY3jrMng4iQSJABddor 1KKo4rycE3NjmoDIUheMndntSd0cL9FbXAa9n4dRNlhoCYOv w_wcB (accessed April 2016).

19. McGlothlin JD, Moenning JE, Cole SS. Evaluation and control of waste anesthetic gases in the postanesthesia care unit. J Perianesth Nurs 2014; 29: 298-312.

20. National Institute for Occupational Safety and Health. Criteria for a Recommended Standard. Occupational Exposure to Waste Anesthetic Gases and Vapors. Washington, D.C., U.S. Department of Health, Education, and Welfare, 1977. Available from URL: http://www.cdc.gov/niosh/pdfs/77-140a.pdf (accessed May 2016).

21. Tannenbaum TN, Goldberg RJ. Exposure to anesthetic gases and reproductive outcome: a review of the epidemiologic literature. J Occup Med 1985; 27: 659-68.

22. Costa Paes ER, Braz MG, Lima JT, et al. DNA damage and antioxidant status in medical residents occupationally exposed to waste anesthetic gases. Acta Cir Bras 2014; 29: 280-6.

23. Eroglu A, Celep F, Erciyes $N$. A comparison of sister chromatid exchanges in lymphocytes of anesthesiologists to nonanesthesiologists in the same hospital. Anesth Analg 2006; 102: 1573-7.

24. Wiesner $G$, Schiewe-Langgartner $F$, Lindner $R$, Gruber $M$. Increased formation of sister chromatid exchanges, but not of micronuclei, in anaesthetists exposed to low levels of sevoflurane. Anaesthesia 2008; 63: 861-4.

25. Hara MR, Kovacs JJ, Whalen EJ, et al. A stress response pathway regulates DNA damage through beta2-adrenoreceptors and beta-arrestin-1. Nature 2011; 477: 349-53.

26. Krajcovicova-Kudlackova $M$, Dusinska $M$. Oxidative DNA damage in relation to nutrition. Neoplasma 2004; 51: 30-3.

27. Andersen $M L$, Ribeiro DA, Bergamaschi CT, et al. Distinct effects of acute and chronic sleep loss on DNA damage in rats. Prog Neuropsychopharmacol Biol Psychiatry 2009; 33: 562-7.

28. Sessler DI. Risks of occupational exposure to waste-anesthetic gases. Acta Anaesthesiol Scand Suppl 1997; 111: 237-9.

29. Smith FD. Management of exposure to waste anesthetic gases. AORN J 2010; 91: 482-94.

30. McGlothlin JD, Moenning JE. Waste anesthetic gases (WAGs) among employees in the healthcare industry. Clinical Foundations 2013; 2013: 1-10. 